https://doi.org/10.48009/1_iis_2010_377-383

\title{
ECONOMIC CONSEQUENCES OF THE SARBANES-OXLEY ACT ON E-COMMERCE FIRMS
}

\author{
Ronald Young, University of New Orleans, rmyoung @uno.edu \\ Hua-Wei Huang, State University of New York at Old Westbury, huangh@oldwestbury.edu \\ Yun-Chia Yan, University of New Orleans, yyan1@uno.edu
}

\begin{abstract}
Regulators and practitioners are concerned about whether SOX Sections 302 and 404 IT-related implementation costs affect the market value of firms in the IT industry. Prior studies indicate that network advantages are the key feature of information-based industries and that E-commerce firms are a major segment of that industry. SOX Section 404 was expected to have significant impact on firms with primary E-commerce risks. In this paper, we find that SOX enactment results in a significant market value decline for these E-commerce firms.
\end{abstract}

Keywords: E-Commerce Firms, Sarbanes-Oxley Act (SOX), Market Value, Cumulative Abnormal Returns

\section{INTRODUCTION}

In 2002, the U.S Congress enacted the SarbanesOxley Act (SOX) in response to a series of corporate financial scandals [1]. Passage of SOX increased the public's attention on IT-related issues. SOX Section 302 requires that the principal executive officer and the principal financial officer certify that the financial statements, and other financial information included in the report, fairly present in all material respects the financial condition and results of operations of the issuing entity and that they have designed such internal controls to ensure that material information relating to the issuer and its consolidated subsidiaries is made known to such officers by others within those entities. Financial data is processed and reported by the company's accounting information system. To maintain the financial reporting accuracy and fairness, an effective IT governance system is absolutely necessary. Bowen et al. (2007) argue that more effective IT governance performance outcomes are associated with a shared understanding of business and IT objectives; active involvement of IT steering committees; a balance of business and IT representatives in IT decisions; and comprehensive and well-communicated IT strategies and policies. Hence, SOX Section 302 strengthens the responsibility of the $\mathrm{CIO}$ and IT staffs, who are in charge of the security and reliability of IT systems.

SOX Section 404 requires that the annual report contain an internal control report, which shall state the responsibility of management for establishing and maintaining an adequate internal control structure and procedures for financial reporting; and contain an assessment, as of the end of the most recent fiscal year of the issuer, of the effectiveness of the internal control structure and procedures of the issuer for financial reporting. Under SOX Section 404 management has to maintain an effective internal control system, including the assessment of IT controls [2]. Haworth and Pietron (2006) indicate that IT departments that have implemented ten categories of IT controls provided by the International Standards Organization (ISO 17799) are well on their way toward SOX compliance. Grant et al. (2008) suggests that (1) deficient IT controls can have widespread impact on the overall internal control structure of a business; and (2) the role of IT in financial reporting systems is destined to escalate.

\section{Impact of SOX on IT industry}

Issues in Information Systems 
Investigation of the impact of SOX on the IT industry is very important to regulators and practitioners. For example, Kumar et al. (2008) use case studies to present major challenges faced by companies in enhancing their enterprise resource planning (ERP) systems for compliance with the SOX [3]. Leih (2006) observed three primary impacts of the SOX mandates on IT project management: (1) an increase in project management formalization, (2) an increase in project duration, and (3) the need to support project management and audit activities with project management software. Arnold et al. (2007) suggests the following impacts of SOX: (1) organizations experienced substantial improvements in enterprise risk management approaches; and (2) organizational flexibility was reduced to various degrees. This reduction in flexibility can in turn negatively affect production cycle times, information technology investment, supply chain performance, and ultimately, market competitiveness. Walker (2008) examined the impact of SOX on companies' enterprise resource planning (ERP) systems and business process management (BPM) tools. Their research suggests that an effective ERP/BPM solution will help an organization achieve a substantial return on investment and improve its business processes and procedures while complying with the SOX Section 404 requirements for internal controls documentation, assessment, and testing. Therefore, SOX Sections 302 and 404 are expected to impose additional ITrelated implementation costs on the IT industry. Grant et al. (2008) suggests that, compared with their peers, companies with IT control deficiencies report more internal control deficiencies, are smaller, pay higher audit fees, and are typically audited by smaller accounting firms.

A prior study indicates that network advantages are the key features of information-based industries (Rajgopa et al. 2003). E-commerce firms are a major segment of that group. SOX Section 404 has brought primary E-commerce risks to the forefront, as companies struggle to address SOX Section 404 requirements related to reporting on internal controls (Sutton et al. 2008). These E-commerce risks include transaction specific capital, information asymmetries, and loss of resource control. In this paper, we test a group of E-commerce firms and show that SOX enactment results in a market value decline for these E-commerce firms.

\section{RESEARCH METHODOLOGY}

Since SOX Sections 302 and 404 are expected to increase the cost burden on the IT industry, the firms' market value should reflect related bad news. Sutton et al. (2008) indicated that SOX Section 404 extends internal controls from direct controls over financial reporting activities to a broader enterprise risk management framework that includes strategic, operational, reputational, regulatory, and information risks. E-commerce firms having high risks of transaction specific capital, information asymmetries, and loss of resource control should negatively respond to SOX Section 404 events. Sabherwal and Sabherwal (2005) documented that economic events such as knowledge management announcements have significant impact on a firm's market value. We can expect that the enactment of SOX also has a similar impact. Hence, our research concentrates on the following research question: Do major SOX events result in a market value decline for major Ecommerce firms?

Our research hypotheses to be tested are as follows:

$\mathrm{H}_{1}$ : There is a significant market value decline around an individual SOX event for E-commerce firms. 
$\mathrm{H}_{2}$ : There is a significant cumulative market value decline resulting from the effects of all SOX events for E-commerce firms.

To test the above hypotheses a sample of $30 \mathrm{E}$ commerce firms are used. Cumulative abnormal returns (CARs) are employed to measure the firms' market value decline (Zhang 2002).

\section{RESULTS}

We initially obtained 92 E-commerce sample firms from www.internet.com as of July 1, 2000. After we match the 92 firms with the CRSP Database, 62 firms were deleted because of missing CARs data. The remaining 30 sample firms are shown in Table 1.

The sample is classified into five industries: auction sites (2 firms), content and community sites (11 firms), E-tailers (11 firms), financial service (3 firms), and portals (3 firms).

\section{Table 1. Sample Firms}

\section{Name}

Priceline Com Inc.

eBay Inc.

Homestore Com Inc.

Artistdirect Inc.

Sportsline Com Inc. Marketwatch.Com

Ivillage Inc.

Edgar Online Inc.

Thestreet.Com Inc.

Quepasa Com Inc.

Switchboard Inc.

Internet.Com Corp

Hoovers Inc.

Expedia Inc.

Bluefly Inc.

Fashionmall Com Inc.

Barnesandnoble Com Inc.

Drugstore Com Inc.

Audible Inc.

Alloy Online

\section{Industry}

Auction sites

Auction sites

Content and community sites

Content and community sites

Content and community sites

Content and community sites

Content and community sites

Content and community sites

Content and community sites

Content and community sites

Content and community sites

Content and community sites

Content and community sites

E-tailers

E-tailers

E-tailers

E-tailers

E-tailers

E-tailers

E-tailers

$\begin{array}{ll}\text { Amazon Com Inc. } & \text { E-tailers } \\ \text { Ticketmaster Online Ctys } & \text { E-tailers } \\ \text { Crosswalk Com Inc. } & \text { E-tailers } \\ \text { InsWeb Corp } & \text { E-tailers } \\ \text { Netbank } & \text { Financial service firms } \\ \text { Ameritrade Holding } & \text { Financial service firms } \\ \text { E Trade Group Inc. } & \text { Financial service firms } \\ \text { Infospace Inc. } & \text { Portals } \\ \text { Yahoo Inc. } & \text { Portals } \\ \text { Ask Jeeves Inc. } & \text { Portals }\end{array}$

In this paper, we select a major SOX event day every month, from Jan 17, 2002 to July 24, 2002, as presented in Table 2:

Table 2: Major SOX Event Days

\begin{tabular}{|c|c|c|}
\hline Event & Date & Content \\
\hline Event 1 & 1/17/2002 & $\begin{array}{l}\text { SEC Chairman proposed an } \\
\text { accounting overhaul plan }\end{array}$ \\
\hline Event 2 & 2/02/2002 & $\begin{array}{l}\text { Treasury Secretary called for } \\
\text { changes in rules governing } \\
\text { corporations }\end{array}$ \\
\hline Event 3 & 3/07/2002 & $\begin{array}{l}\text { Bush's first response to } \\
\text { accounting scandals unveiled }\end{array}$ \\
\hline Event 4 & $4 / 11 / 2002$ & $\begin{array}{l}\text { House Financial Services } \\
\text { Committee scheduled to vote } \\
\text { Oxley's bill, but the vote was } \\
\text { postponed }\end{array}$ \\
\hline Event 5 & $5 / 08 / 2002$ & $\begin{array}{l}\text { Sarbanes circulated his reform } \\
\text { bill in the Senate Banking } \\
\text { Committee }\end{array}$ \\
\hline Event 6 & $6 / 11 / 2002$ & $\begin{array}{l}\text { Democrats on the Senate } \\
\text { Banking Committee united } \\
\text { behind Sarbanes' bill }\end{array}$ \\
\hline Event 7 & 7/24/2002 & $\begin{array}{l}\text { Senate and House agreed on } \\
\text { the final bill }\end{array}$ \\
\hline
\end{tabular}

Table 3 presents returns cumulated over the seven major SOX event days. The mean CARs range from -0.036 to +0.009 , and six of them $(85.7 \%)$ are negative. Three mean CARs of the seven major SOX events are negative and significant at $p$-value $<0.1$ level, which supports our first hypothesis.

The total mean CARs of the seven SOX event days is also negative and significant at $\mathrm{p}$-value $<0.01$ level. This empirical result provides strong evidence to 
support our second hypothesis. The empirical results show that there is a significant cumulative market value decline for E-commerce firms resulting from the effects of both an individual SOX event and all observed SOX events.

\section{Table 3: Cumulative abnormal returns (CARs) around individual SOX events}

\begin{tabular}{lcccc} 
& Window & Mean & T-value & p-value \\
\cline { 2 - 5 } Event 1 & $(-1,+1)$ & 0.009 & 0.85 & 0.40 \\
Event 2 & $(-1,+1)$ & -0.036 & -1.78 & $\mathbf{0 . 0 9 ^ { \star }}$ \\
Event 3 & $(-1,+1)$ & -0.020 & -1.33 & 0.20 \\
Event 4 & $(-1,+1)$ & -0.031 & -2.00 & $\mathbf{0 . 0 5 ^ { \star * }}$ \\
Event 5 & $(-1,+1)$ & -0.004 & -0.16 & 0.88 \\
Event 6 & $(-1,+1)$ & -0.025 & -1.83 & $\mathbf{0 . 0 8 ^ { \star }}$ \\
Event 7 & $(-1,+1)$ & -0.034 & -1.41 & 0.17 \\
Total & $(-1,+1)$ & -0.139 & -2.96 & $\mathbf{0 . 0 1 ^ { * * * }}$
\end{tabular}

$* * *, * *, *$ indicate significance at $1 \%, 5 \%$ and $10 \%$ levels, respectively, two-tailed tests.

Figure 1 shows the descending trend of the mean CARs summations from event 1 to event 7 . On the first event day, the mean CARs is +0.009 , however; on the last event day, the mean CARs summation descends to -0.139 . The significant negative stock return shows that these major SOX events have negative impacts on the market value of E-commerce firms.

\section{Figure 1: Trend of $\Sigma$ CARs}

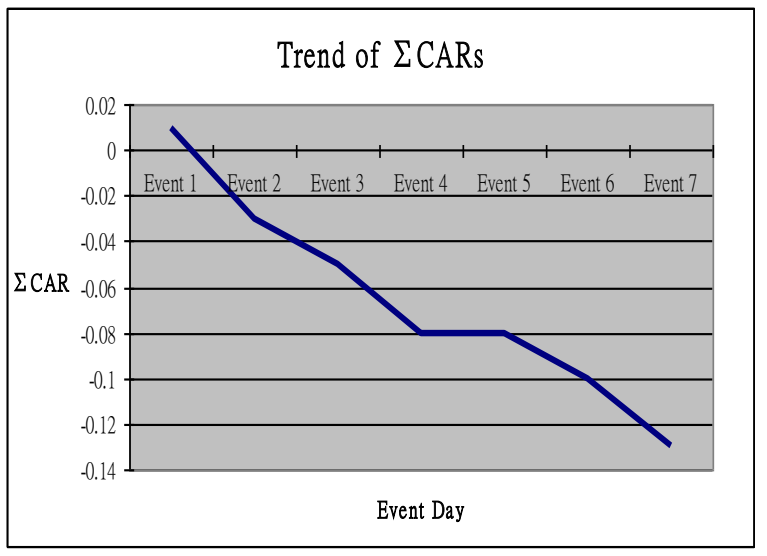

\section{Additional Analysis}

To verify the normal distribution assumption, we provide two tests of normality. Both the Kolmogorov-Smirnova and the Shapiro-Wilk normality tests of $\Sigma$ CARs are insignificant (at $p=0.182$ and $p=0.125$, respectively). The test results show that $\Sigma$ CARs are normally distributed.

Rajgopal et al. (2003) find that network advantages are value relevance to E-commerce firms. They document that network advantages are significantly associated with the following variables:

RD: Research \& development expenses;

MAE: Market \& administrative expenses.

Both RD and MAE are incurred to build network advantages, which results in the variation in stock prices (Rajgopal et al. 2003). Hunter (2003) indicated that both exploratory and exploitation IT investments had significantly negative impacts on the market value of the firm [4]. RD can be viewed as exploratory IT investments because it promotes firm's potential capabilities. MAE can be viewed as exploitative IT investments because it reduces a firm's current capabilities. To investigate how SOX Section 404 impacts E-commerce firms with different network advantages, we test the associations between CAR and RD and MAE. In comparison, we also test the following two traditionally relevant variables of stock prices (Ohlson 1995):

BV: Book value;

IBEI: Income before extraordinary items;

The value relevance theory asserts that reported earnings have information content. Therefore, the influence of IBEI on CAR is expected to be positive and significant. Financial data of the 30 E-commerce 
firms were collected from the Compustat Database, as shown in Table 4.

Table 4: Descriptive Statistics $(\mathrm{N}=30)$

$\begin{array}{lcccc} & \frac{\text { RD/ }}{\text { Sales }} & \frac{\text { BV } /}{\text { Assets }} & \frac{\text { IBEI/ }}{\text { Sales }} & \frac{\underline{\text { MAE } /}}{\text { Sales }} \\ \text { Mean } & 0.11 & 0.42 & -4.62 & 0.56 \\ \text { Median } & 0.05 & 0.70 & -0.23 & 0.46 \\ \text { Std } & 0.20 & 0.77 & 22.4 & 0.41\end{array}$

To control the size effects, we deflate the balance sheet variables by total assets, and the income statement variables by total sales. Table 5 reports the Pearson correlation coefficients. The traditional relevant variable, IBEI/Sales, is positively significant at $p=0.01$ level.

$\mathrm{RD} /$ Sales has a significant negative association with $\Sigma$ CARs, at the $p=0.02$ level. Therefore, SOX Section 404 requirements may reduce exploratory $\mathrm{RD}$ investments and this may be viewed as negative information to market investors. MAE/Sales has a significant positive association with $\Sigma$ CARs at the $p=0.04$ level. Exploitative MAE investments eliminated by the internal control system may be regarded as positive information to market investors. The empirical results show that SOX has a negative (positive) impact on the market prices of these Ecommerce firms with higher RD (higher MAE) expenditures.

Table 5: Pearson Correlation Coefficients $(\mathrm{N}=30)$

\begin{tabular}{|c|c|c|c|c|}
\hline & $\frac{\mathrm{RD} /}{\underline{\text { Sales }}}$ & $\underline{\text { BV } /}$ & $\frac{\text { IBEI/ }}{\underline{\text { Sales }}}$ & $\frac{\text { MAE/ }}{\underline{\text { Sales }}}$ \\
\hline & Coefficient & Coefficient & Coefficient & Coefficient \\
\hline & $p$-value & $p$-value & $p$-value & $p$-value \\
\hline \multirow[t]{2}{*}{ CAR1 } & -0.13 & 0.04 & 0.12 & -0.01 \\
\hline & 0.51 & 0.84 & 0.52 & 0.96 \\
\hline \multirow[t]{2}{*}{ CAR2 } & 0.06 & 0.19 & -0.02 & 0.12 \\
\hline & 0.74 & 0.30 & 0.92 & 0.51 \\
\hline \multirow[t]{2}{*}{ CAR3 } & 0.08 & 0.12 & 0.02 & 0.16 \\
\hline & 0.66 & 0.54 & 0.91 & 0.40 \\
\hline
\end{tabular}

\begin{tabular}{lcccc} 
CAR4 & 0.25 & 0.24 & -0.12 & 0.21 \\
& 0.18 & 0.21 & 0.54 & 0.27 \\
CAR5 & -0.57 & -0.27 & 0.65 & 0.10 \\
& $\mathbf{0 . 0 0 ^ { * * }}$ & 0.15 & $\mathbf{0 . 0 0 ^ { * * }}$ & 0.60 \\
CAR6 & 0.03 & 0.14 & 0.05 & 0.11 \\
& 0.87 & 0.45 & 0.80 & 0.56 \\
CAR7 & -0.50 & -0.33 & 0.48 & 0.25 \\
& $\mathbf{0 . 0 0 ^ { * * }}$ & $\mathbf{0 . 0 8 ^ { * }}$ & $\mathbf{0 . 0 1 ^ { * * }}$ & 0.18 \\
& & & & \\
\multirow{2}{*}{ ¿CARs } & -0.42 & -0.05 & 0.57 & 0.38 \\
& $\mathbf{0 . 0 2}^{*}$ & 0.78 & $\mathbf{0 . 0 0 ^ { * * }}$ & $\mathbf{0 . 0 4}^{*}$
\end{tabular}

**, * indicate significance at $5 \%$ and $10 \%$ levels, respectively (two-tailed tests).

\section{CONCLUSIONS}

The impact of SOX on the business environment has been far-reaching since it is the most important reform of U.S. business practices since the Securities Exchange Act of 1934. The requirements of SOX Sections 302 and 404 have direct influences on the IT industry and market participants' perception about IT firms, therefore; empirical evidence to showcase this market effect is indispensible. Based upon the results of our study, we concluded that there was a significant market value decline in the major SOX event days. The market investors viewed SOX events as negative signals for the IT industry. Our results provide strong evidence that a significant cost burden of SOX implementation impacts E-commerce firms. Our results reinforce the findings of Sutton et al. (2008) that SOX extends internal control requirements to a broader enterprise risk management frame and increases additional IT and E-commerce risks to public companies. Our study also contributes to practice and standard setters. Firms in the IT industry have to place importance on both SOX Sections 302 and 404. The success of SOX implementation improves financial statement accuracy and therefore reduces risks of material misstatements, resulting in an increase in investors' confidence. Finally, our study is one of a few event 
studies for the IT industry [5]. We believe that our findings provide contributions to the extant IT-related literature.

The following research limitation applies. This study focuses on the impact of SOX on market value of Ecommerce firms. The empirical data of E-commerce firms is so difficult to obtain that the very limited sample size unavoidably reduces the significance of the variables.

Section 407 of SOX, Disclosure of Audit Committee Financial Expert, is another important section that may affect the IT industry. DeFond et al. (2005) suggested that there was a positive market reaction to the appointment of accounting experts assigned to audit committees. Pathak et al. (2010) recently found evidence showing that IT and communication expertise are positively associated with expertise in audit judgment of E-commerce. Future studies can investigate whether new appointments of IT experts to audit committees have an impact on firms' market value.

\section{NOTES}

[1] For examples, Enron, Tyco International, Adelphia, Peregrine Systems and WorldCom. These scandals cost investors billions of dollars when the share prices of the affected companies collapsed.

[2] IT controls that typically fall under the scope of SOX 404 assessment may include: specific application (transaction processing) control procedures, IT general controls, and IT operations controls.

[3] Their results show that (1) in all companies, existing ERP systems were not able to meet all control requirements without some modifications;

(2) control implementations have been long, complicated and costly processes, which are not fully completed; (3) detailed analyses and documentation of existing systems, controls and processes were required in all companies; (4) the protection of systems security and the segregation of duties were perceived to be major technical obstacles.

[4] Exploratory IT investments mean IT investments which involve the exploration of firm's new capabilities; exploitative IT investments mean IT investments which entail the exploitation of firm's current capabilities (Hunter 2003).

[5] Sabherwal and Sabherwal (2005) examined the CARs of 89 firms' knowledge management (KM) announcements from 1995 to 2002. Their results show that KM announcements have a short-term positive impact on firms' value in some conditions. Khallaf and Skantz (2007) found evidence that quality characteristics of newly appointed CIO are associated with market's reaction to appointment announcements.

\section{REFERENCES}

1. Arnold V, Benford T. S., Canada J, Kuhn Jr. J. R., Sutton S. G. (2007). The unintended consequences of Sarbanes-Oxley on technology innovation and supply chain integration. Journal of Emerging Technologies in Accounting. Vol. 4; p. 103.

2. Bowen P. L, Cheung M. Y. D., Rohde F. H. (2007). Enhancing IT governance practices: A model and case study of an organization's efforts. International Journal of Accounting Information Systems. Vol. 8, Iss. 3; p. 191.

3. DeFond, M., R. N. Hann and X. Hu. (2005). Does the market value financial expertise on audit committees of boards of directors? Journal of Accounting Research. 43 (2): 153-193.

4. Grant G. H, Miller K. C, Alali F. (2008). The effect of IT controls on financial reporting. 
Managerial Auditing Journal. Vol. 23, Iss. 8; p. 803.

5. Haworth D. A, Pietron L. R (2006). SarbanesOxley: achieving compliance by starting with ISO 17799. Information Systems Management. Vol. 23, Iss. 1; p. 73.

6. Hunter S. D. (2003). Information technology, organizational learning, and the market value of the firm. Journal of Information Technology Theory and Application. Vol. 5, Iss. 1; pg. 1.

7. Khallaf A, T. R Skantz. (2007). The effects of information technology expertise on the market value of a firm. Journal of Information Systems. 21, 1; pg. 83.

8. Kumar V, Pollanen R, Maheshwari B. (2008). Challenges in enhancing enterprise resource planning systems for compliance with SarbanesOxley Act and analogous Canadian legislation. Management Research News. Vol. 31, Iss. 10; p. 758.

9. Leih M. J (2006). The impact of the SarbanesOxley act on it project management. Journal of Information Technology Theory and Application. Vol. 8, Iss. 3; p. 13.

10. Ohlson J. (1995). Earnings, book value, and dividends in security valuation. Contemporary Accounting Research 11: 161-82.

11. Pathak J., M. R. Lind, and M. J. Abdolmohammadi. (2010). E-commerce audit judgment expertise: Does expertise in system change management \& information technology auditing mediate E-commerce audit judgment expertise? Informatica Economica. Vol. 14, No. 1.

12. Rajgopal, S., Venkatachalam, M., \& Kotha, S. (2003). The value relevance of network advantages: the case of E-commerce firms. Journal of Accounting Research, 41(1), 135-162.

13. Sabherwal R., Sabherwal S. (2005) Knowledge management using information technology: determinants of short-term on firm value. Decision Sciences. 36, 4. pg. 531.

14. Sutton S. G., Khazanchi. D, Hampton. C. and Arnold. V. (2008) Risk analysis in extended enterprise environments: identification of critical risk factors in B2B E-Commerce relationships. Journal of the Association for Information Systems, Vol. 9, Nos. 3-4, pp. 151-174.

15. Walker K. B. (2008), SOX, ERP, and BPM: A trifecta that can make your business run better. Strategic Finance. Vol. 90, Iss. 6; pg. 47-54.

16. Zhang, I. X. (2007). Economic consequences of the Sarbanes-Oxley Act of 2002. Journal of Accounting and Economics 44, 74-115. 